\title{
The Influence of Learning Models of Natural Materials on the Cognitive and Motoric Development of Children in Group B in Kindergarten
}

\author{
Malikatus Sholihah, Wahyu Sukartiningsih, \& Bachtiar Syaiful Bachri \\ Universitas Negeri Surabaya \\ Surabaya, Indonesia \\ malikaachmad@gmail.com
}

\begin{abstract}
This study aims to determine the effect of learning model of natural materials focused on the cognitive and motor development of children of group B in Kindergarten. The learning model is a chance for children to learn through the center of natural materials. It is also giving chance to the children to show explorative activities, probing and exploring with various media and activities. Based on observations made in kindergarten using the model of natural materials center, they are still less exploring the cognitive and motor development because they were still passive in the activity.
\end{abstract}

This research uses quantitative approach with QuasiExperimental research model with Pretest-Posttest and Control Group Design. The research subjects were children of Group B Dukuh Pakis District Surabaya at TK Khadijah 2 (pre-elementary or kindergarten school) and TK Ar-rasyid. The sample used Simple Random Sampling, where there were 30 children (TK B1 and TK B2) from TK Khadijah 2 and 25 children were (TK B1 and TK B2) from Ar-Rasyid Kindergarten. The data was collected by observation method, documentation and interview. Testing the first and second hypothesis was performed in term of using One Way ANOVA test, while the third hypothesis used Multivariate Analysis of Variance (MANOVA) test to see how the influence of all dependent variables relates. MANOVA was used to test the hypothesis about the effect of two dependent variables. Hypothesis testing was rejected if $\mathrm{HO}$ (Hypothesis of Nil) was rejected, $\mathrm{H} 1$ (Alternative Hypothesis) was accepted if the value of $F$ count $\geq F$ table and if $\mathrm{HO}$ (Hypothesis of Nil) was accepted, H1 (Alternative Hypothesis) was rejected if the price of $F$ count $\leq F$ table.

Keywords - Learning Model of Natural Materials Center, Cognitive Development, Motoric.

\section{INTRODUCTION}

Early childhood education is a child's early foothold which is gained from coaching to optimize the potential of self-owned explores various things about surroundings and actively undertakes activities. Early childhood education is expected to be able to motivate to keep learning through science that will be very useful later in the coming future. Early childhood education is education for growth and development, physical and spiritual out of the family environment before entering primary education. The time period also plays an important role for children, therefore the educational activities should be provided through playing while learning and learning while playing. The aim is to encourage children to gain the desired knowledge as a tool for learning activities, rather than trying to teach the knowledge in teaching [1]

One of the interesting learning models and many implemented ones in current early childhood learning center model is based on Mutiah opinion [2] saying that Model of learning centers approach is analytical study conducted within the "circle" (circle times) and is focused for playing.

The circle means when teachers sit with children with a circular position to give a foothold to the child performance. Before and after the play centers, a child zone is equipped with a set of tools to play that served as the foothold environment needed to develop the entire basic potential progress in various aspects of development in a balanced way 
Structural play gives children the opportunity to engage in activities directed at goals that are fun and exciting. Structured play provides an opportunity to maintain attention and to store information in mind in the context of peer interaction (4).

Center for natural materials is based on (8) saying that a place for children in doing activities with the various right tools is in accordance with the needs of children. They are consisting of tools/dry ingredients and tools/materials using water [4]. In learning natural materials centers, children learn to take advantage of a wide range of tools and media that are made from natural or those which are available from nature. For example play water, and play using a variety of tools.

Science is built in a person through a process of continuous interaction with the environment. According to cognitivist, the psychology of learning is seen as an attempt to understand something with the way new of knowledge to relate the structure of existing thinking. An attempt is made actively by the child. The liveliness that can either be looking for experience, seeking information, solving problems, observing environment, or pulling something to achieve a particular goal. So, previous knowledge belonging to is largely determining the success of learning new knowledge of information.

In Pratisti [5]Piaget stated that children will build their own cognitive world because children are able to process information accepted to develop their new ideas (7). Theory of cognitive development is on Piaget's cognitive development (6). According to the theory, a child learning occurred gradually, the environment is not able to influence the development of the child's knowledge. A child cannot receive the knowledge directly and cannot directly use such knowledge, but the knowledge will be gained gradually by means of active learning and relying on school surroundings [2]
Integrating playing in early education institution function to remain a serious task, while imaginative function is to maintain children to try, experiment and innovate, as well as direct them to be creative as an asset in a knowledge-based and community-based learning (5).

According to Lerner in [4], it states that the fine motor skills is an ability to use media with coordination between the eye and the hand (8). Based on the definition above, it can be concluded the child's fine motor ability of children functions to perform an activity with regard to the motion control of small muscles (smooth) and requires careful coordination (9).

Learning in kindergarten has its own characteristics, it is not just to acquire such knowledge, but how to grow and gain the knowledge to optimize all aspects of the development in accordance with the principles of early childhood learning. Based on these characteristics, the implication for the implementation of the study is determined. Educators should have the competence to manage, plan such learning, and have an educational and fun side.

\section{METHODS}

The study entitled "the effect of Model Learning Center in Natural Materials on the development of fine motor and Cognitive Children in kindergartens" used quantitative research approach with the method of experimentation.

According to Margono [6] quantitative research is a process of discovering knowledge that use data in the form of numbers as a tool to find information on what will be known. Quantitative research can be implemented with a descriptive research. This research is quasi-correlation experiments, research and experimentation. The model used in this study was a model of Quasi-alphabets experiment with one kind of treatment (2). 
The design of this research can be described as follows:

Table 2.1 Research Design Model of PretestPosttest Control Group Design

\begin{tabular}{|c|c|c|c|}
\hline $\mathrm{E}$ & $\mathrm{O} 1$ & $\mathrm{X}$ & $\mathrm{O} 2$ \\
\hline $\mathrm{K}$ & $\mathrm{O} 3$ & - & $\mathrm{O} 4$ \\
\hline
\end{tabular}

Description:

E : Experimental Group

$\mathrm{K}:$ Control group

O1 : Experimental Group before treatment

O2 : Experimental Group after treatment

X : Treatment (Model Learning Center Natural Material)

O3 : A control group before the treatment

O4 : The control group after the treatment

- : No treatment (Model Learning Center preparation)

This study used a Simple Random Sampling because of the process of taking the samples which was from a population of members. It was done randomly without regarding to existing strata in that population. This way was done when members of the population are considered homogeneous.

Based on the review, the number of samples in the study consisting of 55 children using Simple Random Sampling, where 30 children (KINDERGARTEN KINDERGARTEN B1 and B2) are from TK Khadija2 and 25children

(KINDERGARTEN KINDERGARTEN B1 and B2) are from TK Ar-Rasyid. So the subjects used in the study can be stated as follows:
Table 2.2 Sample Research Experiment and Control Groups Development

\begin{tabular}{|c|c|c|c|c|}
\hline $\begin{array}{c}\text { Institution } \\
\text { name }\end{array}$ & \multicolumn{2}{|c|}{$\begin{array}{c}\text { Experimental } \\
\text { Group }\end{array}$} & \multicolumn{2}{c|}{ Control Group } \\
\cline { 2 - 5 } & Group & $\begin{array}{c}\text { Number } \\
\text { of } \\
\text { students }\end{array}$ & Group & $\begin{array}{c}\text { Number } \\
\text { of } \\
\text { students }\end{array}$ \\
\hline $\begin{array}{c}\text { TK } \\
\text { Khadijah } \\
2\end{array}$ & B1 & 15 & B2 & 15 \\
\hline $\begin{array}{c}\text { TK Ar- } \\
\text { Rasyid }\end{array}$ & B1 & 13 & B2 & 12 \\
\hline \multicolumn{2}{|c|}{ Total } & 28 & Total & 27 \\
\hline
\end{tabular}

Both kindergartens were made as a sample research with the consideration that in every preschool, it is applied Learning Center model. It allows the natural materials and also the number of participants was in sufficient population representing the kindergarten in Dukuh Pakis Surabaya. The collection of data used in this research was in term of the observation and documentation.

Testing the validity of the research instrument was performed by using the technique of correlation of Product Moment. It is by using computer-assisted program or SPSS for Windows Evaluation, Version 21.0. Testing reliability was performed by using Cronbach Alpha formula, with the assistance of computer program of SPSS for Windows Evaluation Version 21.0. If the value of Cronbach Alpha is greater than 0.70 , an invalid constructs or variables research is said to be reliable to be used as the input in the process of analyzing data to test the hypothesis.

According to Ghozali [7]testing the hypothesis of the first and second should involve following process: the first and second used One Way Anova test, while the third hypothesis test used Multivariate Analysis of Variance (MANOVA). It is a test to see how the influence of all the variables are bound (10). MANOVA was used to test hypotheses about the influence of two variables. 
Hypothesis testing was done using 0.05 significant levels then:

a. H0 (Null Hypothesis) was rejected, H1 (alternative hypothesis) was accepted if the value of $\mathrm{F}$ count $\geq$ F table

b. H0 (Null Hypothesis) was accepted, H1 (alternative hypothesis) was denied if the value of $\mathrm{F}$ count $\leq$ F table

\section{RESULTS AND DISCUSSION}

Research instrument was (11) a tool or a means to facilitate the work of researchers in collecting data by means of measurements [8]. Testing instrument of the research was obtained from validation sheet of testing instruments and rubric assessment of model Learning Center natural materials on the development of cognitive and fine motor.

1. The grating instruments observation of natural materials centers on children Cognitive development

Table 3.1 Latticework of Instruments Of Observation Centers Natural Materials On Children's Cognitive

\begin{tabular}{|c|c|c|c|}
\hline Variable & $\begin{array}{l}\text { The Level of } \\
\text { Achievement of } \\
\text { The Child's } \\
\text { Development }\end{array}$ & & ndicator \\
\hline \multirow[t]{2}{*}{$\begin{array}{l}\text { Cognitive } \\
\text { Child }\end{array}$} & $\begin{array}{lr}\text { Solving } & \text { simple } \\
\text { problems } & \text { in } \\
\text { everyday life } & \end{array}$ & & $\begin{array}{l}\text { Fill water } \\
\text { into a glass }\end{array}$ \\
\hline & $\begin{array}{l}\text { appliying the } \\
\text { knowledge } \\
\text { experience in the } \\
\text { context of the } \\
\text { New } \\
\text { things }\end{array}$ & & $\begin{array}{l}\begin{array}{l}\text { Pour red } \\
\text { dye in to } \\
\text { the glass }\end{array} \\
\text { Pour dye } \\
\text { in to blue } \\
\text { glass } \\
\text { Pour dye } \\
\text { in to yellow } \\
\text { glass }\end{array}$ \\
\hline
\end{tabular}

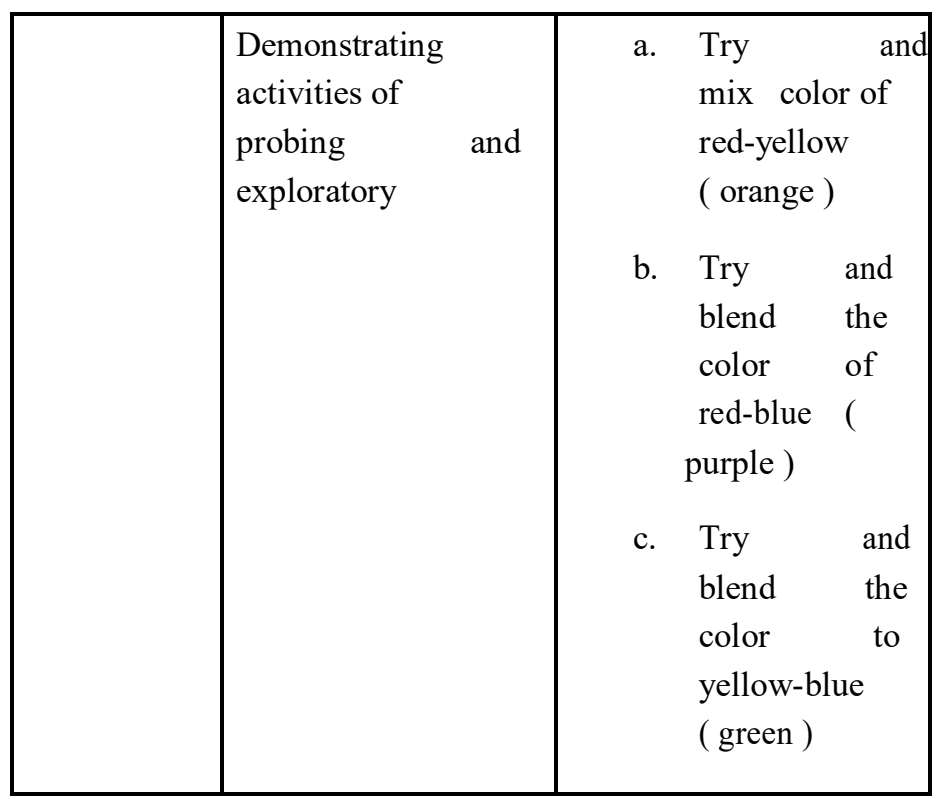

2. The grating instrument observations of natural materials centers on fine motor development of children

Table 3.2 Grating instrument observations of natural materials centers on fine motor development of Children

\begin{tabular}{|c|c|c|}
\hline Variable & $\begin{array}{c}\text { The level of } \\
\text { Achievement } \\
\text { of The } \\
\text { child's } \\
\text { development }\end{array}$ & Indicator \\
\hline \multirow[t]{2}{*}{$\begin{array}{l}\text { Children } \\
\text { Fine } \\
\text { Motoric }\end{array}$} & $\begin{array}{l}\text { Exploring } \\
\text { with various } \\
\text { media }\end{array}$ & $\begin{array}{lc}\text { a. } & \text { Experimenting } \\
\text { with water } \\
\text { b. Experimenting } \\
\text { with dyes } \\
\text { c. Experimenting } \\
\text { with dyes stirring } \\
\text { spoon }\end{array}$ \\
\hline & $\begin{array}{l}\text { Using cutlery } \\
\text { properly }\end{array}$ & $\begin{array}{l}\text { Using glass and } \\
\text { wash it properly } \\
\text { b. Using a spoon and } \\
\text { wash it properly }\end{array}$ \\
\hline
\end{tabular}




\section{CONCLUSION}

Based on the experiment and discussion, it could be concluded that: (1) the center model was in term of the learning approach carrying out the "circle" and the center of play. (2) The learning process was done by using 4 steps, namely the arrangement of tools, footing before playing, footing during playing, and footing after playing. (3) In the center of natural materials children can explore various media and activities, and children show activities that are explorative which stimulate children's cognitive and motoric development.

\section{REFERENCES}

[1] A. A. Gencer and M. Gonen, "Examination of The Effects of Reggio Emilia Based Projects on Preschool Children's Creative Thinking Skills," ProcediaSocial Behav. Sci., vol. 186, pp. 456-460, 2015.

[2] R. Muthiah, "A Study On The Remediation Of Disorders In The Speaking Ability Of The Slow Learners In VI Standard Taught Under Activity Centred Teaching Of English," IOSR J. Res. Method Educ., vol. 4, no. 6, pp. 1-9, 2014.

[3] M. Fadlillah, Edutainment Pendidikan Anak Usia Dini: Menciptakan Pembelajaran Menarik, Kreatif dan Menyenangkan. Prenada Media, 2016.

[4] B. Sujiono, "dkk. 2008," Metod. Pengemb. Fis.

[5] W. D. Pratisti, "Psikologi anak usia dini," Jakarta PT. Indeks, 2008.

[6] D. Darmawan, "Metode penelitian kuantitatif." Bandung: PT Remaja Rosdakarya, 2013.

[7] S. Santoso, Statistik nonparametrik. Elex Media Komputindo, 2001.

[8] P. Sugiyono, “Dr. 2010," Metod. Penelit. Kuantitatif, Kualitatif, dan R\&D. Bandung CV Alf. 